\title{
Effect of FOCUS-PDCA procedure on improving self-care ability of patients undergoing colostomy for rectal cancer
}

\author{
Efeito do procedimento FOCUS-PDCA na melhoria da capacidade de \\ autocuidado de pacientes submetidos a colostomia por câncer retal \\ Efecto del procedimiento FOCUS-PDCA en la mejora de la capacidad de \\ autocuidado de los pacientes sometidos a colostomía por cáncer de recto
}

How to cite this article:

Jin Y, Li C, Zhang X, Jin Y, Yi L, Cui J. Effect of FOCUS-PDCA procedure on improving self-care ability of patients undergoing colostomy for rectal cancer. Rev Esc Enferm USP. 2021;55:e03729. doi: https://doi.org/10.1590/S1980-220X2020012503729

\section{Yingai Jin ${ }^{1}$ \\ Chunyu Li ${ }^{2}$ \\ Xian Zhang ${ }^{1}$ \\ Yan Jin ${ }^{1}$ \\ Liping $\mathrm{Yi}^{1}$ \\ D Jinhua Cui ${ }^{1}$}

${ }^{1}$ Yanbian University, Department of General Surgery Affiliated Hospital of Yanbian, Yanji City, Jilin, China.

2 Yanbian University, Nursing

College, Yanji City, Jilin, China.

\begin{abstract}
Objective: To investigate the effect of the FOCUS-PDCA procedure on the self-care ability of patients undergoing colostomy for rectal cancer. Method: A nonrandomized controlled trial of 160 patients with rectal cancer undergoing colostomy. The control group received routine nursing intervention, and the observation group received the FOCUSPDCA procedure. The self-care ability of the two groups was investigated 1 week and 1 month after surgery, and a comparative analysis was made between the groups. Results: One week after surgery, the self-care ability of rectal cancer patients with colostomy increased from 39.09 points before implementation of the FOCUS-PDCA procedure to 60.15 points after implementation; an increase of $21.06 \%$. One month after surgery, the self-care ability increased from 61.50 points to 83.13 points after implementation of the FOCUS-PDCA procedure; an increase of $21.63 \%$. Conclusion: Application of the FOCUS-PDCA procedure improved the self-care ability of rectal cancer patients undergoing colostomy, improved their physical and mental health, reduced colostomy complications, and improved their quality of life. The results suggest that it is worth applying FOCUS-PDCA more widely.
\end{abstract}

\section{DESCRIPTORS}

Quality Management; Colostomy; Rectal Neoplasms; Self Care; Aptitude; Oncology Nursing. 


\section{INTRODUCTION}

Colorectal cancer is the fourth most life-threatening cancer ${ }^{(1)}$, and some rectal cancer patients need permanent or preventive colostomy ${ }^{(2)}$. Although this kind of surgical treatment has saved patients' lives, it also changes the normal defecation route, and this can have a negative effect on psychological, physical and social activities, affecting quality of life. The self-care ability of rectal cancer patients with colostomy has a direct impact on their health and ultimately affects their quality of life ${ }^{(3)}$. There is an urgent need for medical staff to improve the self-care ability of patients undergoing colostomy for rectal cancer.

The PDCA cycle was originally proposed by Walter A. Shewhart in the 1930s. In the 1950s, it was adopted by American quality management expert W. Edward Deming and began to be used in enterprise management; then, it was widely used in quality management. PDCA is recognized by management as an effective work procedure and one of the effective quality management methods ${ }^{(4)}$. The FOCUS-PDCA procedure is an extension and perfection of the PDCA cycle. The aim is to understand all aspects of the process more carefully in order to achieve the goal of continuous quality improvement. FOCUS-PDCA is a continuous quality improvement management plan put forward by the American Hospital Organization in the 1990s, and it has undergone a long development process from enterprise management to hospital management. Since the 20th century, FOCUS-PDCA has been applied to central laboratory management ${ }^{(5)}$, critical case management ${ }^{(6)}$, ventilator-associated pneumonia management of inpatients ${ }^{(7)}$, and family nursing $^{(8)}$. Implementation of the FOCUS-PDCA procedure is divided into 9 steps, including 5 FOCUS steps and 4 PDCA cycles $^{(6)}$. The purpose of the FOCUS procedure is to identify potential problems, and the most important aspect of PDCA is to achieve continuous quality improvement. In the present study, we applied the FOCUS-PDCA procedure to the selfcare ability of rectal cancer patients undergoing colostomy.

\section{METHOD}

\section{Study Design}

A nonrandomized controlled trial study.

\section{SCENARIO}

According to the particularity and ethics of the disease, the segmented convenience method was used to select rectal cancer cases. A total of 80 patients with rectal cancer undergoing colostomy from October 2018 to March 2019 were selected as the control group, and they were given routine nursing. A total of 80 patients with rectal cancer undergoing colostomy from April to September 2019 were selected as the observation group. The FOCUS-PDCA procedure was applied to the observation group. The self-care ability of the patients was investigated and compared at 1 week and 1 month after surgery.

Inclusion criteria for colostomy in patients with rectal cancer were: (1) all patients were diagnosed with rectal cancer by pathological and imaging examination and underwent colostomy; (2) all patients were aware of the disease and had normal communication skills; and (3) all patients volunteered to participate in the study. The exclusion criteria for colostomy in patients with rectal cancer were: (1) cognitive impairment or mental abnormality; (2) other malignant tumors or severe heart, brain, liver, kidney or lung diseases; and (3) illiteracy, upper limb disability or poor self-care ability.

The control group comprised 52 men (65.0\%) and 28 women (35.0\%), with a mean $\pm \mathrm{SD}$ age of $62.6 \pm 8.27$ years when the patients underwent colostomy surgery. Sixty-eight patients (85.0\%) were without stoma-related complications and $12(15.0 \%)$ had colostomy-related complications. The observation group comprised 49 men (61.25\%) and 31 women $(38.75 \%)$, with a mean age of $64.2 \pm 8.34$ years when the patients underwent colostomy surgery. Seventy patients (87.5\%) were without stoma-related complications and 10 (12.5\%) had colostomy-related complications. Detailed data are shown in Table 1.

Table 1 - Sociodemographic Characteristics - Yanji City, Jilin Province, China, 2018-2019.

\begin{tabular}{|c|c|c|c|c|}
\hline & $\begin{array}{c}\text { Control } \\
\text { group } \\
\mathrm{n}=\mathbf{8 0}\end{array}$ & $\begin{array}{c}\text { Observation } \\
\text { group } \\
\mathrm{n}=\mathbf{8 0}\end{array}$ & $t / \chi^{2} / Z$ & $P$ \\
\hline \multicolumn{5}{|l|}{ Age } \\
\hline $\begin{array}{l}\text { Mean age } \\
\text { (standard } \\
\text { deviation) }\end{array}$ & $62.6 \pm 8.27$ & $64.2 \pm 8.34$ & $-1.189^{\#}$ & 0.236 \\
\hline$\leq 55$ & $14(17.5 \%)$ & $13(16.25 \%)$ & $-0.036^{\&}$ & 0.971 \\
\hline $56-65$ & $28(35 \%)$ & $30(37.5 \%)$ & & \\
\hline $66-75$ & $32(40 \%)$ & $30(37.5 \%)$ & & \\
\hline$\geq 75$ & $6(7.5 \%)$ & $7(8.75 \%)$ & & \\
\hline Sex & & & $0.242^{*}$ & 0.623 \\
\hline Male & $52(65.0 \%)$ & $49(61.25 \%)$ & & \\
\hline Female & $28(35.0 \%)$ & $31(38.75 \%)$ & & \\
\hline Complications & & & $0.211^{*}$ & 0.646 \\
\hline $\begin{array}{l}\text { With } \\
\text { complications }\end{array}$ & $12(15.0 \%)$ & $10(12.5 \%)$ & & \\
\hline $\begin{array}{l}\text { No } \\
\text { complications }\end{array}$ & $68(85.0 \%)$ & $70(87.5 \%)$ & & \\
\hline Education & & & $-0.507^{\&}$ & 0.612 \\
\hline None or Basic & $16(20 \%)$ & $12(15 \%)$ & & \\
\hline $\begin{array}{l}\text { Secondary or } \\
\text { vocational }\end{array}$ & $48(60 \%)$ & $52(65 \%)$ & & \\
\hline University & $16(20 \%)$ & $16(20 \%)$ & & \\
\hline Marital status & & & $2.535^{*}$ & 0.469 \\
\hline Married & $48(60 \%)$ & $52(65 \%)$ & & \\
\hline $\begin{array}{l}\text { Separated- } \\
\text { divorced }\end{array}$ & $12(15 \%)$ & $14(17.5 \%)$ & & \\
\hline Widowed & $15(18.75 \%)$ & $8(10 \%)$ & & \\
\hline Single & $5(6.25 \%)$ & $6(7.5 \%)$ & & \\
\hline \multicolumn{2}{|c|}{ Employment status } & & $1.558^{*}$ & 0.816 \\
\hline $\begin{array}{l}\text { Occupational } \\
\text { activity }\end{array}$ & $13(16.25 \%)$ & $15(18.75 \%)$ & & \\
\hline Retired & $30(37.5 \%)$ & $33(41.25 \%)$ & & \\
\hline Self-employed & $14(17.5 \%)$ & $10(12.5 \%)$ & & \\
\hline Employee & $18(22.5 \%)$ & $15(18.75 \%)$ & & \\
\hline Others & $5(6.25 \%)$ & $7(8.75 \%)$ & & \\
\hline
\end{tabular}

Note: ${ }^{*}$ independent sample t-test was used for comparison between the two

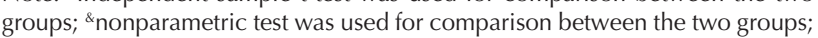
${ }^{*}$ chi-square test was used for comparison between the two groups. 


\section{Data Collection}

The FOCUS-PDCA procedure was adopted to continuously improve any problems found. The specific implementation steps were as follows.

F (Find problems): during operation of the colostomy nursing clinic in our hospital, it was found that the self-care ability of colostomy patients was at a low level, and most of the patients came from grass-roots hospitals.

O (Organize): to improve the self-care ability of colostomy patients, a continuous quality improvement (CQI) team composed of doctors, nurses, international enterostomy therapists, psychological counselors and managers defined the division of labor and implementation progress.

$\mathrm{C}$ (Clarify): CQI members referred to the International ESCA (Electron Spectroscopy for Chemical Analysis) selfcare ability scale ${ }^{(9)}$ and developed a self-care ability test table for patients undergoing colostomy. There were 25 items, 11 items queried self-care knowledge, 8 self-care skills, and 6 self-care attitude. Items were scored using a ranked (ordinal) scale of 0 to 4 points, where a score of 0 indicated a low level of self-care and $4 \mathrm{a}$ high level. The 25 scored items generated a cumulative score ranging from 0 to 100 points, with higher scores indicating higher levels of self-care. Administration of the instrument by a CQI member required 20 minutes. The details are shown in Chart 1.
Chart 1 - Self-care ability checklist for colostomy patients - Yanji City, Jilin Province, China, 2018-2019.

\begin{tabular}{|l|l|}
\hline Dimension & Item \\
\hline \multirow{5}{*}{$\begin{array}{l}\text { Self-care } \\
\text { knowledge }\end{array}$} & $\begin{array}{l}\text { The importance and function of colostomy } \\
\text { Normal colostomy shape and color } \\
\text { Colostomy chassis, accessory product functions } \\
\text { The judgement and change timing of colostomy pocket leak } \\
\text { Related knowledge of diet and clothing after colostomy } \\
\text { Related knowledge about sleep and motion after colostomy } \\
\text { Bathing method after colostomy } \\
\text { Related knowledge about sexual life after colostomy } \\
\text { Identification and prevention of colostomy complication } \\
\text { Time, frequency, place and method of postoperative follow-up }\end{array}$ \\
\hline Self-care & $\begin{array}{l}\text { Method for emptying feces in colostomy pocket } \\
\text { Method of removing the colostomy chassis } \\
\text { skills }\end{array}$ \\
$\begin{array}{l}\text { Method of measuring the size of a colostomy } \\
\text { Clipping method of colostomy pocket } \\
\text { Method of observe and clean the skin around the colostomy } \\
\text { Method of pasting the colostomy chassis } \\
\text { Method for dealing with various colostomy complications } \\
\text { Proper use of colostomy attachment products }\end{array}$ \\
\hline Self-care \\
attitude & $\begin{array}{l}\text { Read books on colostomy frequently } \\
\text { Know self-stress relief and reasonable vent } \\
\text { Know the benefits and barriers to healthy behavior } \\
\text { Actively communicate with medical staff } \\
\text { Visit the colostomy clinic regularly and see the doctor in time } \\
\text { Be confident in your own healthy behaviors }\end{array}$ \\
\hline
\end{tabular}

$\mathrm{U}$ (Understand): according to the above survey, CQI members analyzed the root causes using a fishbone diagram from 5 aspects of personnel, equipment, materials, system and environment through brainstorming ${ }^{(9)}$, as shown in Figure 1.
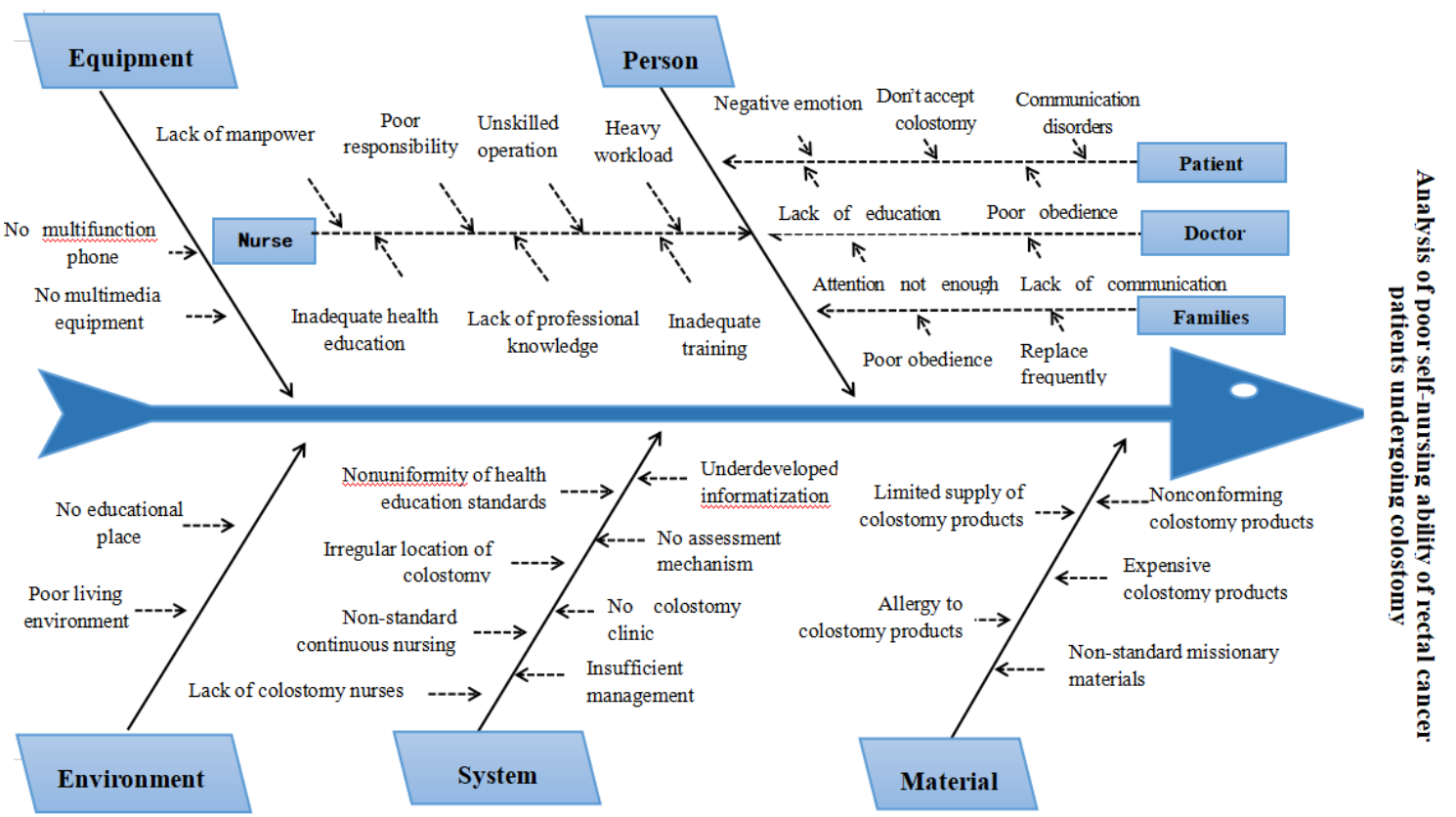

Figure 1 - Fishbone diagram of low self-care ability of rectal cancer patients undergoing colostomy in Yanji City, Jilin Province, China, 2018.

Nine factors were selected by score, and Plato was drawn after 9 factors were regraded, following the Pareto rule ${ }^{(10)}$, as shown in Figure 2. The four reasons for the cumulative percentage of $75.91 \%$ were the nonstandard continuous nursing, inadequate health education, lack of professional knowledge, and no assessment mechanism. This was ultimately the root cause why the CQI team needed to improve. 


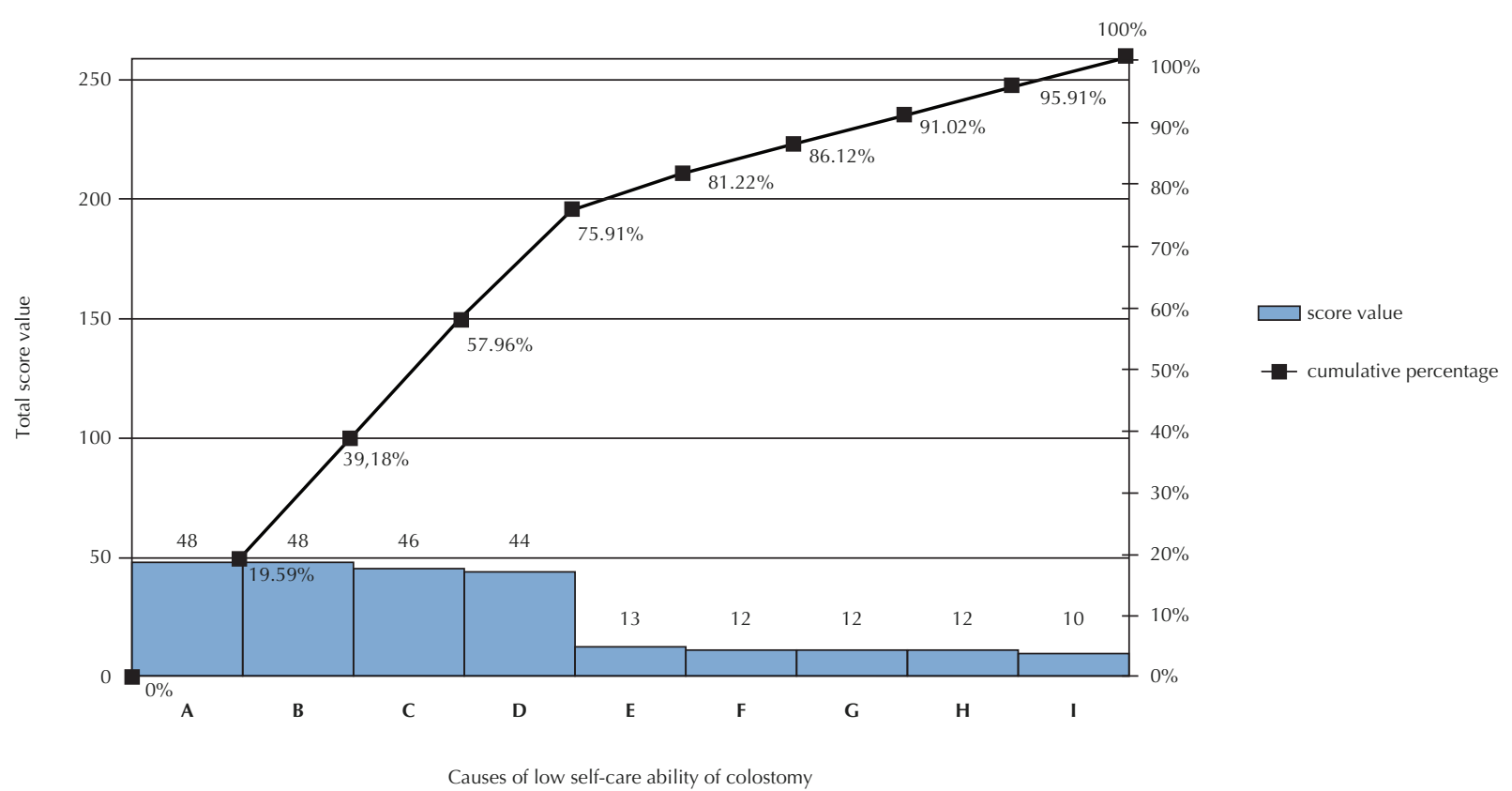

Notes: A: nonstandard continuous nursing; B: inadequate health education; C: no assessment mechanism; D: lack of professional knowledge; E: irregular location of colostomy; F: lack of manpower; G: underdeveloped informatization; H: limited supply of colostomy products; I: poor patient obedience.

Figure 2 - Plato's method was used to analyze the reasons for the low self-care ability of patients undergoing colostomy in Yanji City, Jilin Province, China, 2018.

S (Select): in view of the above four root causes leading to the decline in self-care ability of colostomy patients, members of the CQI team formulated and decided to implement corresponding countermeasures to improve continuous nursing services, implement standardized health education, establish self-evaluation of colostomy patients, and strengthen professional knowledge training.

$\mathrm{P}$ (Plan): set the target value according to the working ability of CQI members: the score of self-care ability reached 60 points within 1 week after surgery, and the score of selfcare ability reached $>80$ points within 1 month after surgery.

$\mathrm{D}$ (Do): at present, continuous nursing is mainly carried out through telephone follow-up, family visit, colostomy fraternity, colostomy outpatient follow-up and other forms, but these forms continue the nursing cycle, methods and publicity content has no standardized process. In order to solve this problem, the following measures were taken: (1) to uniformly formulate the nodes, contents, methods and tools of colostomy to extend the nursing time to 1 month, to achieve standardization; (2) to establish nursing platforms such as WeChat groups, official accounts and QQ groups of doctors and patients by using information systems to carry out remote monitoring and guidance to improve patient compliance; (3) to provide fully personalized nursing services according to the patients' physical, psychological and social needs, to encourage patients to return to society as soon as possible; and (4) bring the telephone follow-up rate of discharged patients up to the evaluation standard of nursing quality, which is linked to nursing performance, so as to improve the attention of medical staff to continuous nursing.

The CQI group formulated the preoperative and postoperative health education plan for colostomy patients, carried out according to the schedule, and realized the whole process of health education, as detailed in Chart 2.

Chart 2 - Preoperative and postoperative health education plan for patients with colostomy - Yanji City, Jilin Province, China, 2019.

\begin{tabular}{|l|l|}
\hline $\begin{array}{l}\text { Implementation } \\
\text { time }\end{array}$ & Item \\
Before & $\begin{array}{l}\text { Talk about the importance of colostomy surgery } \\
\text { Tell the way of colostomy surgery } \\
\text { The importance of colostomy positioning } \\
\text { Colostomy pocket wearing method and experience } \\
\text { Psychological guidance and actively undergo } \\
\text { surgery } \\
\text { Distribute and guide the colostomy care booklet }\end{array}$ \\
\hline After enterostomy & $\begin{array}{l}\text { Instruct patients how to select and store colostomy } \\
\text { pocket, } \\
\text { Colostomy attachment products and } \\
\text { announcements } \\
\text { Colostomy pocket replacement process: remove- } \\
\text { check-clean-measure-tailor-paste } \\
\text { Instruct the tips for removing colostomy chassis, } \\
\text { cutting and pasting colostomy pockets } \\
\text { Methods and observation points for preventing } \\
\text { colostomy complications } \\
\text { Patient's diet,clothing,activities and social health } \\
\text { guidance and announcements } \\
\text { Introduce the contents of sunshine lecture hall, } \\
\text { colostomy clinic and colostomy association } \\
\text { Set up the WeChat group and pay attention to } \\
\text { Wechat official accounts } \\
\text { Psychological guidance to encourage patients to } \\
\text { step into society } \\
\text { Correct sexual life guidance }\end{array}$ \\
\hline
\end{tabular}

Medical staff provide patients with a large amount of health information in a variety of ways, but ultimately, patients' awareness and compliance directly affect their self-care ability. The CQI team established a set of procedures to evaluate the self-care ability of patients undergoing 
colostomy, by patients' self-evaluation and medical staff's self-evaluation, which were before surgery, after surgery and before discharge. The evaluation included observing the normal color and function of colostomy, the method of changing pockets, the identification and prevention of colostomy complications, and the guidance of matters needing attention in daily life. Ensure that healthy behavior is implemented.

Nurses are the direct caregivers, propagandists and managers of patients. The theoretical knowledge and skills mastered by nurses directly affect the health outcome of patients ${ }^{(11)}$.Members of the CQI team developed a multilevel training program to popularize the theoretical knowledge and operational skills related to colostomy nursing. The theoretical training was mainly based on multimedia teaching, and the operational skills training was mainly based on the job visit mode, combined with case analysis of colostomy complications to improve the nurses' ability to identify and solve problems. Through the implementation of the FOCUSPDCA plan. The nurses were tested in theory and operation.

$\mathrm{C}$ (Check): during implementation of the countermeasures, the responsibility is borne by the individual. Before and after implementation, the same scale was used to investigate the patients' self-care ability 1 week and 1 month after surgery, and the results were statistically analyzed.

A (Action): CQI team members judged whether running the FOCUS-PDCA plan achieved the desired results. If the effect was obvious, we formulated relevant standardized procedures for further promotion and application. If there were deficiencies in the implementation, then we formulated corrective measures to bring the unfinished work into the next PDCA cycle for continuous improvement, to constantly improve the self-care ability of patients, and finally achieve the desired goals.

\section{DATA ANALYSIS AND PROCESSING}

SPSS 22.0 was used for statistical analysis, measurement data: in line with normal distribution, using independent sample t-test, paired measurement data using paired t-test; counting data: classification differences were compared by chi-square test; rank sum test was used to compare grade differences.

\section{ETHICAL ASPECTS}

The study was conducted between 2018 and 2019. All procedures were approved by the Ethics Committee of Affiliated Hospital of Yanbian University (No. 2020159) and were in line with national regulations relating to human research.

\section{RESULTS}

From October 2018 to March 2019, we used 25 scoring items to check the self-care ability of 80 patients undergoing colostomy for rectal cancer. Self-care ability at 1 week and 1 month after surgery was 39.09 and 61.50 points, respectively, which seriously affected the quality of life of patients after surgery. According to the above survey, to improve the self-care ability of patients with colostomy, CQI members analyzed the root causes using a fishbone diagram of five aspects of personnel, equipment, materials, system and environment through brainstorming. The four reasons for the cumulative percentage of $75.91 \%$ were nonstandard continuous nursing, inadequate health education, lack of professional knowledge, and no assessment mechanism. This was the root cause why the CQI team needed to improve, and finally decided to implement the FOCUS-PDCA plan. The scores of nurses in the theory test and operation test improved from 67.95 to 90.56 points and 78.63 to 95.56 points, respectively. After implementation of FOCUS-PDCA, from April 2019 to September 2019, the self-care ability of 80 rectal cancer colostomy patients increased from 39.09 to 60.15 points; an increase of $21.06 \%$. One month after implementation of FOCUS-PDCA, the self-care ability of patients increased from 61.50 to 83.13 points; an increase of $21.63 \%$. The difference was significant $(\mathrm{P}<0.01)$, as shown in Table 2.

Table 2 - Comparison of self-care ability scores before and after FOCUS-PDCA implementation - Yanji City, Jilin Province, China, 2019.

\begin{tabular}{cccc}
\hline & $\begin{array}{c}\text { Number } \\
\text { of } \\
\text { patients }\end{array}$ & $\begin{array}{c}\text { Self-care ability } \\
\mathbf{1} \text { week after } \\
\text { operation (score) }\end{array}$ & $\begin{array}{c}\text { Self-care ability at 1 } \\
\text { month after operation } \\
\text { (score) }\end{array}$ \\
\hline $\begin{array}{c}\text { Control } \\
\text { group }(\overline{\mathrm{X}} \pm \mathrm{s})\end{array}$ & 80 & $39.09 \pm 15.71$ & $60.15 \pm 11.32$ \\
$\begin{array}{c}\text { Observation } \\
\text { group }\end{array}$ & 80 & $61.50 \pm 8.98$ & \\
$(\overline{\mathrm{X}} \pm \mathrm{S})$ & & & $83.13 \pm 7.15$ \\
Increase $(\%)$ & & $21.06 \%$ & \\
$\boldsymbol{t}$ & & 38.651 & $21.63 \%$ \\
$\boldsymbol{P}$ & $<0.01$ & 49.895 \\
\end{tabular}

\section{DISCUSSION}

In recent years, with the application of the Enhanced Recovery After Surgery (ERAS) concept of accelerated rehabilitation surgery, rectal cancer patients with colostomy can reach the discharge indication 7 days after colostomy ${ }^{(12)}$. During this week, patients not only have to accept the changed route of fecal excretion, but also master the operational skills related to colostomy nursing, which is a major challenge for patients. The changes in patients' health knowledge, skill level and self-concept directly affect self-care ability, and ultimately the quality of life and health outcome $\mathrm{e}^{(3)}$. We ran the FOCUS-PDCA program to analyze the factors that affected the self-care ability of colostomy patients by fishbone diagram, Plato and Pareto rules, focusing on the key problems that needed to be solved, and achieved the best results in a short time by taking more effective and targeted intervention measures. After using the FOCUS-PDCA procedure, the self-care ability of patients with rectal cancer colostomy increased significantly by $21.06 \%$ and $21.63 \%$ 1 week and 1 month after colostomy, respectively and the difference was statistically significant.

At present, there are various forms of in-hospital and out-of-hospital nursing for colostomy patients, such as telephone follow-up, family visit, colostomy fraternity, and colostomy outpatient follow-up. How to effectively combine these nursing modes in order to maximize the effect is a difficult problem that our CQI group needs to solve. Therefore, 
we integrated the above nursing models, from admission to discharge, discharge to family, to develop specific nursing content, cycle, methods and processes to achieve standardization. At the same time, we established an evaluation system for self-care ability of colostomy patients, find the deficiency in time, and analyzed the weaknesses, in order to improve the self-care ability of colostomy patients.

On the basis of evidence-based guidelines, the CQI team members created relevant self-care manuals and standardized tables for colostomy, and applied them in clinical practice. The contents of self-care manuals included physiological anatomy, surgical methods, daily life management, emotional management, pocket replacement methods, correct selection of colostomy accessories, and complication management, which can meet the needs of patients with pictures and texts.
In the process of using FOCUS-PDCA, various standardized forms were created, such as an examination table of self-care ability of colostomy, and a health education planning table before and after colostomy, to meet the homogenization standard of nursing quality management.

\section{CONCLUSION}

In this study, FOCUS-PDCA was applied to the self-care management of rectal cancer patients undergoing colostomy, which can improve patients' self-care ability, improve their physical and mental condition, reduce the complications of colostomy, and improve their quality of life. Our results should be confirmed in a study with a larger number of participants.

\section{RESUMO}

Objetivo: Investigar o efeito do procedimento FOCUS-PDCA na habilidade de autocuidado de pacientes submetidos a colostomia por câncer retal. Método: Um ensaio clínico não randomizado com 160 pacientes com câncer retal submetidos a colostomia. $\mathrm{O}$ grupo controle recebeu intervenção de enfermagem de rotina, e o grupo observação recebeu o procedimento FOCUS-PDCA. A capacidade de autocuidado dos dois grupos foi investigada por 1 semana e 1 mês após a cirurgia, e foi feita uma análise comparativa entre os grupos. Resultados: Em uma semana após a cirurgia a capacidade de autocuidado de pacientes com câncer retal com colostomia aumentou de 39,09 pontos antes da implementação do procedimento FOCUS-PDCA para 60,15 pontos após a implementação; um aumento de 21,06\%. Em um mês após a cirurgia, a capacidade de autocuidado aumentou de 61,50 pontos para 83,13 pontos após a implantação do procedimento FOCUS-PDCA; um aumento de 21,63\%. Conclusão: A aplicação do procedimento FOCUS-PDCA melhorou a capacidade de autocuidado de pacientes com câncer retal submetidos a colostomia, melhorou sua saúde física e mental, reduziu as complicações da colostomia e melhorou sua qualidade de vida. Os resultados sugerem que vale a pena aplicar o FOCUS-PDCA de forma mais ampla.

\section{DESCRITORES}

Gestão da Qualidade; Colostomia; Neoplasias Retais; Autocuidado; Aptidão; Enfermagem Oncológica.

\section{RESUMEN}

Objetivo: Investigar el efecto del procedimiento FOCUS-PDCA sobre la capacidad de autocuidado de pacientes sometidos a colostomía por cáncer de recto. Método: Un ensayo controlado no aleatorizado de 160 pacientes con cáncer de recto sometidos a colostomía. El grupo de control recibió una intervención de enfermería de rutina y el grupo de observación recibió el procedimiento FOCUS-PDCA. La capacidad de autocuidado de los dos grupos se investigó 1 semana y 1 mes después de la cirugía, y se realizó un análisis comparativo entre los grupos. Resultados: En una semana después de la cirugía la capacidad de autocuidado de los pacientes con cáncer de recto con colostomía aumentó de 39,09 puntos antes de la implementación del procedimiento FOCUS-PDCA a 60,15 puntos después de la implementación; un aumento del 21,06\%. En un mes después de la cirugía, la capacidad de autocuidado aumentó de 61,50 puntos a 83,13 puntos después de la implementación del procedimiento FOCUS-PDCA; un aumento del 21,63\%. Conclusión: La aplicación del procedimiento FOCUS-PDCA mejoró la capacidad de autocuidado de los pacientes con cáncer de recto sometidos a colostomía, mejoró su salud física y mental, redujo las complicaciones de la colostomía y mejoró su calidad de vida. Los resultados sugieren que vale la pena aplicar FOCUS-PDCA de manera más amplia.

\section{DESCRIPTORES}

Gestión de la Calidad; Colostomía; Neoplasias del Recto; Autocuidado; Aptitud; Enfermería Oncológica.

\section{REFERENCES}

1. Bray F, Ferlay J, Soerjomataram I, Siegel RL, Torre LA, Jemal A. Global cancer statistics 2018: GLOBOCAN estimates of incidence and mortality worldwide for 36 cancers in 185 countries. CA Cancer J Clin. 2018;68(6):394-424. doi: 10.3322/caac.21492

2. Arnold M, Sierra MS, Laversanne M, Soerjomataram I, Jemal A, Bray F. Global patterns and trends in colorectal cancer incidence and mortality. Gut. 2017;66(4):683-91. doi: http://dx.doi.org/10.1136/gutjnl-2015-310912

3. Abdalla MI, Sandler RS, Kappelman MD, Martin CF, Chen W, Anton K, et al. The impact of ostomy on quality of life and functional status of Crohn's Disease patients. Inflamm Bowel Dis. 2016;22(11):2658-64. doi: https://doi.org/10.1097/MIB.0000000000000930

4. Glenn GR. Nursing: Concepts of Practice. AORN J. 1981;34(4):776. doi: https://doi.org/10.1016/S0001-2092(07)62310-2

5. Näsvall P, Dahlstrand U, Löwenmark T, Rutegård J, Gunnarsson U, Strigård K. Quality of life in patients with a permanent stoma after rectal cancer surgery. Qual Life Res. 2017;26(1):55-64. doi:https://doi.org/10.1007/s11136-016-1367-6

6. Collado-Boira EJ, Machancoses FH, Temprado MD. Development and validation of an instrument measuring self-care in persons with a fecal ostomy. J Wound Ostomy Continence Nurs. 2018;45(4):335-40. doi: https://doi.org/10.1097/WON.0000000000000444

7. Edmondss J, Zagami M. QI team shares ownership and gets results. J Healthc Qual. 1992;14(5):24-8. doi: https://doi. org/10.1111/j.1945-1474.1992.tb00231.x

8. Evers GCM, Isenberg MA, Philipsen H, Senten M, Brouns G. Validity testing of the Dutch translation of the appraisal of self-care agency ASA scale. Int J Nurs Stud. 1993;30(4):331-42. doi: https://doi.org/10.1016/0020-7489(93)90105-4 
9. Rivet EB. Ostomy management: a model of interdisciplinary care. Surg Clin North Am. 2019;99(5):885-98. doi: https://doi.org/10.1016/j. suc.2019.06.007

10. Naoum V, Kyriopoulos D, Charonis A, Athanasakis K, Kyriopoulos J. The Pareto Principle ("80-20 Rule") In Healthcare Services In Greece. Value Health. 2016;19(7):618. doi: https://doi.org/10.1016/j.jval.2016.09.1563

11. Aoun SM, Stegmann R, Slatyer S, Hill KD, Parsons R, Moorin R, et al. Hospital post discharge intervention trialled with family caregivers of older people in Western Australia: potential translation into practice. BMJ Open. 2018;8(11):e022747. doi: http://dx.doi.org/10.1136/ bmjopen-2018-022747

12. Vignali A, Elmore $U$, Cossu A, Lemma M, Cali B, Nardi $P$, et al. Enhanced recovery after surgery (ERAS) pathway vs traditional care in laparoscopic rectal resection: a single-center experience. Tech Coloproctol. 2016;20(8):559-66. doi: https://doi.org/10.1007/s10151016-1497-4

Acknowledgments:

We thank Cathel Kerr, BSc, PhD, from Liwen Bianji, Edanz Editing China (www.liwenbianji.cn/ac), for editing the English text of a draft of this manuscript. 